\title{
Effect of Dietary Protein on Rat Renin and Angiotensinogen Gene Expression
}

Mark E. Rosenberg, David Chmielewski, and Thomas H. Hostetter

Department of Medicine, University of Minnesota, Minneapolis, Minnesota 55455

\begin{abstract}
Plasma renin activity varies with the level of dietary protein, being higher on a high protein diet. To explore the molecular mechanisms underlying this relationship we first examined the effect of dietary protein on renin and angiotensinogen gene expression at the level of steady state mRNA in male Sprague-Dawley rats. Renal renin mRNA was higher on a $50 \%$ (high) compared to a $6 \%$ (low) protein diet both $3 \mathrm{~d}(9.4 \pm 1.1$ vs. $5.3 \pm 0.4 \mathrm{pg} / \mu \mathrm{g}$ of total RNA; $P<0.02)$ and $21 \mathrm{~d}(6.8 \pm 1.0$ vs. $3.5 \pm 0.4 \mathrm{pg} / \mu \mathrm{g}$ of total RNA; $P<0.02)$ after dietary change. No change occurred in either renal or liver angiotensinogen mRNA. When three levels of dietary protein were examined, renal renin mRNA was elevated on a $50 \%$ and lowered on a $6 \%$ protein diet compared to a more standard $20 \%$ protein diet. Kidney weights and renal protein, RNA, and RNA/DNA increased with the level of dietary protein reflecting protein-induced renal hypertrophy. Uninephrectomy resulted in no change in renin mRNA compared to sham operation (3.7 \pm 0.1 vs. $3.4 \pm 0.1 \mathrm{pg} / \mu \mathrm{g}$ RNA; $P=\mathrm{NS})$ despite renal growth in the uninephrectomy group implicating dietary protein and not hypertrophy as the major factor for stimulating renin $\mathrm{mRNA}$. In conclusion, the level of dietary protein is a novel and specific stimulus for changes in renal renin mRNA. The increased plasma renin activity on a high protein diet is due at least in part to increased renin synthesis. (J. Clin. Invest. 1990. 85:1144-1149.) angiotensin II • hypertrophy $\bullet$ uninephrectomy • growth • mRNA
\end{abstract}

\section{Introduction}

Dietary protein intake has profound effects on both the healthy and diseased kidney. Several hormonal alterations accompany variations in dietary protein intake including changes in glucagon, glucocorticoids, aldosterone, and prostaglandins (1-6). Plasma renin activity also varies with the level of dietary protein, being higher on a high protein diet when examined in normal rats and humans, and in patients with a variety of glomerular diseases $(3-5,7,8)$. In the setting of renal disease, the interaction between dietary protein and the reninangiotensin system has important pathophysiological implica-

Presented in part at the 1989 Annual Meeting of the American Federation for Clinical Research, Washington, DC, and published in abstract form in 1989. (Clin. Res. 37: 500a.)

Address reprint requests to Dr. Rosenberg, University of Minnesota, Department of Medicine, Box 736 UMHC, 516 Delaware St., SE, Minneapolis, MN 55455.

Received for publication 3 March 1989 and in revised form 17 November 1989

J. Clin. Invest.

(c) The American Society for Clinical Investigation, Inc.

0021-9738/90/04/1144/06 \$2.00

Volume 85, April 1990, 1144-1149 tions in view of the effects of angiotensin II on the renal microcirculation (9).

Examination of the mRNA for renin has provided insights into local renin-angiotensin systems and into the factors responsible for increases in plasma renin activity. For example, renin mRNA increases during sodium depletion and converting enzyme inhibition suggesting that in these conditions increased renin synthesis is in part responsible for the rise in plasma renin activity $(10,11)$. The purpose of this study was to examine whether dietary protein affects renin gene expression at the level of steady state mRNA. The mRNA for the renin substrate angiotensinogen was also examined in both the kidney and liver. Since increases in dietary protein lead to renal growth we have also examined another stimulus to renal growth, that of contralateral nephrectomy.

\section{Methods}

Experimental design. The study involved two groups of experiments. The first series of experiments examined the effect of dietary protein on renal renin and angiotensinogen mRNA and liver angiotensinogen mRNA. 32 male Sprague-Dawley rats weighing $225-250 \mathrm{~g}$ were placed on a low $(6 \%)$ protein diet for $1 \mathrm{wk}$ at which time they were assigned to either continue on the low protein diet $(n=16)$ or were switched to a high ( $50 \%)$ protein $\operatorname{diet}(n=16)$. At $3 \mathrm{~d}(n=10$ both groups) and $21 \mathrm{~d}$ ( $n=6$ both groups), the left kidney and a portion of the liver were removed, snap-frozen in liquid nitrogen, and stored at $-70^{\circ} \mathrm{C}$ for subsequent RNA extraction. To examine another renal growth stimulus, 22 male Sprague-Dawley rats weighing 225-250 g were subjected under methohexital anesthesia $(5 \mathrm{mg} / 100 \mathrm{~g}$ body wt) to either right uninephrectomy $(n=11)$ or sham operation $(n=11)$. These rats were maintained on standard rat chow containing $\sim 23 \%$ protein (Ralston Purina Co., St. Louis, MO). $7 \mathrm{~d}$ after operation the left kidney was removed, snap-frozen in liquid nitrogen, and stored at $-70^{\circ} \mathrm{C}$ for either RNA extraction or measurement of renal protein, RNA, and DNA content.

In the second experiment the effects of three levels of dietary protein on renal renin mRNA and renal protein, RNA, and DNA content were examined. 18 male Sprague-Dawley rats weighing 225-250 g were placed on a $6 \%$ protein diet for $1 \mathrm{wk}$. They were then assigned to either a low $(6 \%)$, normal $(20 \%)$, or high $(50 \%)$ protein diet for $3 \mathrm{~d}$ at which time the kidneys were removed, snap-frozen in liquid nitrogen, and stored at $-70^{\circ} \mathrm{C}$. RNA was extracted from the left kidney for renin hybridization studies and the right kidney was homogenized in water and aliquots taken for measurement of protein, RNA, and DNA.

Diets. The composition of the three semisynthetic diets were (in $\mathrm{g} / \mathrm{kg}$ ): 6\% protein (Teklad Diet TD83437, Teklad, Madison, WI) 69 casein, 150 cornstarch, 611 sucrose, 49 corn oil; $20 \%$ protein (Teklad Diet 170597$) 230$ casein, 150 cornstarch, 471 sucrose, 48 corn oil; $50 \%$ protein (Teklad Diet 170598) 575 casein, 150 cornstarch, 171 sucrose, 44 corn oil. The diets were isocaloric and had identical electrolyte contents containing (in $\mathrm{g} / \mathrm{kg}$ ): $0.76 \mathrm{Na}, 2.68 \mathrm{~K}$, and $0.74 \mathrm{Cl}$. A constant dietary fat level was maintained by adjusting the level of corn oil to compensate for the fat contributed by casein.

RNA extraction and Northern blot hybridization. Total RNA from liver and kidney was isolated using a modification of the guanidine-hydrochloride procedure (12). The RNA was dissolved in sterile water and RNA concentrations determined by absorbance readings at 260 
$\mathrm{nm}$. A260/A280 ratios averaged $2.00 \pm 0.03$ in livers and $1.94 \pm 0.03$ in kidneys. Aliquots $(20 \mu \mathrm{g})$ of total RNA from liver and kidney were electrophoresed in a $1 \%$ agarose gel containing $20 \mathrm{mM}$ MOPS, $1 \mathrm{mM}$ EDTA, $5 \mathrm{mM}$ sodium acetate $\mathrm{pH} 7.0$, and $2.2 \mathrm{M}$ formaldehyde and transferred to nitrocellulose membranes (13). In each gel the position of the $28 \mathrm{~S}$ and $18 \mathrm{~S}$ ribosomal RNA was determined in a separate lane by ethidium bromide staining. The size estimates for the signals were checked by the use of a ${ }^{32} \mathrm{P}$-labeled DNA ladder. The nitrocellulose membranes were heated at $80^{\circ} \mathrm{C}$ in vacuo for $2 \mathrm{~h}$, prehybridized at $60^{\circ} \mathrm{C}$ for $4 \mathrm{~h}$ in a buffer containing $5 \times \mathrm{SSC}, 5 \times$ Denhardt's reagent, 50 $\mathrm{mM}$ Tris-hydrochloride, $\mathrm{pH} 7.5,0.1 \%$ sodium pyrophosphate, $0.2 \%$ SDS, $200 \mu \mathrm{g} / \mathrm{ml}$ sonicated, denatured salmon testes DNA, and 100 $\mu \mathrm{g} / \mathrm{ml}$ yeast tRNA. The membranes were then hybridized at $42^{\circ}$ with nick-translated cDNA probes (see below) for $16-18 \mathrm{~h}$ in a buffer containing 50\% formamide (deionized), $5 \times$ SSC, $1 \times$ Denhardt's reagent, $50 \mathrm{mM}$ Tris-hydrochloride, $\mathrm{pH} 7.5,0.1 \%$ sodium pyrophosphate, $1 \%$ SDS, $100 \mu \mathrm{g} / \mathrm{ml}$ salmon testes DNA, and $100 \mu \mathrm{g} / \mathrm{ml}$ yeast plus RNA. The membranes were washed for $45 \mathrm{~min}$ in $2 \times$ SSC, $0.1 \%$ SDS twice at room temperature and once at $60^{\circ}$, and were then washed in $0.2 \times$ SSC and $0.1 \%$ SDS at $60^{\circ}$ for $45 \mathrm{~min}$. Autoradiographs (Kodak XAR-5 film) were obtained and quantitated by computer-assisted videodensitometry (14).

Solution hybridization. The presence of a single band for renin mRNA (1,600 bp) and angiotensinogen mRNA ( 1,800 bp) on hybridization of the nitrocellulose filters permitted quantitation of the respective mRNAs by solution hybridization based on a modification of the technique of Durnam and Palmiter (15). Total kidney RNA $(20-50 \mu \mathrm{g})$ and liver RNA (0.5 to $2 \mu \mathrm{g})$ was hybridized with $\sim 20,000$ $\mathrm{cpm}$ of a ${ }^{35} \mathrm{~S}$-labeled renin or angiotensinogen cRNA at $80^{\circ} \mathrm{C}$ in $20 \mu \mathrm{l}$ $0.6 \mathrm{M} \mathrm{NaCl}, 20 \mathrm{mM}$ Tris- $\mathrm{HCl}, \mathrm{pH} 6.5,5 \mathrm{mM}$ EDTA, $2.5 \%$ ethanol, and $0.1 \%$ SDS. The samples were digested with $1 \mathrm{ml}$ RNase solution (RNase A [25 $\mu \mathrm{g} / \mathrm{ml}$ ], RNase T1 [250 U/ml], $0.3 \mathrm{M} \mathrm{NaCl}, 10 \mathrm{mM}$ Tris- $\mathrm{HCl}, \mathrm{pH} 7.5,2 \mathrm{mM}$ EDTA, and $75 \mu \mathrm{g}$ salmon testes DNA) to digest unhybridized probe, precipitated with trichloroacetic acid, and quantified by liquid scintillation counting. A standard curve was constructed using mRNA transcribed by SP6 RNA polymerase after linearization of the renin plasmid by Hind III and the angiotensinogen plasmid by Xba I (2-10,000 pg).

cDNAs and preparation of the $C D N A$ and $c R N A$ probes. The renin cDNA (pRen44.ceb) and angiotensinogen cDNA (pRang 6) had both been subcloned into the plasmid pGEM-4 (Promega Biotec, Madison, WI) (cDNAs were gifts of K. R. Lynch) $(16,17)$. For preparation of the cDNA probe, both cDNAs were nick-translated with $\left[{ }^{32} \mathrm{P}\right] \mathrm{dCTP}(3,000$ $\mathrm{Ci} / \mathrm{mmol}$; ICN Biomedicals, Irvine, $\mathrm{CA}$ ) to a specific activity of 1-2 $\times 10^{8} \mathrm{cpm} / \mu \mathrm{g}$ DNA. For preparation of the cRNA probes, the renin and angiotensinogen plasmids were first linearized with the restriction enzymes Bam HI and Sst I, respectively. $250 \mu \mathrm{Ci}$ of $\left[{ }^{35}\right.$ S]UTP $(1320$ $\mathrm{Ci} / \mathrm{mmol}$; New England Nuclear, Wilmington, $\mathrm{DE}$ ) was evaporated to dryness in a microfuge tube and the following added: $1 \mu \mathrm{g}$ of the linearized cDNA, $2.5 \mu \mathrm{l}$ water, $2.0 \mu \mathrm{l} 5 \times$ buffer $(200 \mathrm{mM}$ Tris-HCl, $\mathrm{pH}$ $7.5,30 \mathrm{mM} \mathrm{MgCl}_{2}, 10 \mathrm{mM}$ spermadine), $1.0 \mu 1100 \mathrm{mM}$ dithiothreitol, $0.5 \mu \mathrm{l} \mathrm{RNasin}(40 \mathrm{U} / \mu \mathrm{l}), 2.0 \mu \mathrm{l}$ NTP $(2.5 \mathrm{mM}$, without UTP), and 1.0 $\mu \mathrm{l}$ T7 RNA polymerase (18). The mixture was incubated for $60 \mathrm{~min}$ at $37^{\circ} \mathrm{C}$. The reaction mixture was DNase-treated and unincorporated nucleotides removed by chromatography on a Sephadex G50 column.

Laboratory methods. Sodium concentration was measured by flame photometry from two consecutive 24-h urine collections in a subset of rats. Protein content was measured from an aliquot of homogenized kidney using Coomassie blue dye (Bio-Rad Laboratories, Richmond, CA). For RNA determination $2.5 \mathrm{ml}$ of cold $2.1 \mathrm{~N}$ perchloric acid $\left(\mathrm{HClO}_{4}\right)$ was added to duplicate 5-ml aliquots of homogenized kidney (approximately $250 \mathrm{mg}$ of wet weight tissue) (19). After standing for $15 \mathrm{~min}$ on ice, the precipitate was separated by centrifugation and washed twice with cold $0.7 \mathrm{~N} \mathrm{HClO}_{4}$. The $\mathrm{HClO}_{4}$ was carefully drained off and $4 \mathrm{ml}$ of $0.3 \mathrm{~N} \mathrm{KOH}$ was added. Digestion was carried out in a $37^{\circ} \mathrm{C}$ water bath for $1 \mathrm{~h}$. The samples were then neutralized with $10 \mathrm{~N} \mathrm{HClO}_{4}$ and acidified with 1 vol of $1 \mathrm{~N} \mathrm{HClO}_{4}$. The precipitate was separated by centrifugation and washed twice with cold $0.5 \mathrm{~N}$
$\mathrm{HClO}_{4}$. The combined supernatant fluid and washings were diluted to $30 \mathrm{ml}$, and the RNA quantitated by absorbance readings at $260 \mathrm{~nm}$. For DNA determination $6 \mathrm{ml}$ of cold $0.2 \mathrm{~N} \mathrm{HClO}_{4}$ was added to $4 \mathrm{ml}$ of homogenized kidney ( $\sim 200 \mathrm{mg}$ of wet weight tissue) $(20)$. The precipitate was separated by centrifugation and washed three times with $0.2 \mathrm{~N} \mathrm{HClO}_{4}$. After addition of $4 \mathrm{ml}$ of $0.5 \mathrm{~N} \mathrm{HClO}_{4}$, the samples were incubated in a $90^{\circ} \mathrm{C}$ water bath for $20 \mathrm{~min}$, and then centrifuged. $1 \mathrm{ml}$ of the supernatant was combined with $1 \mathrm{ml}$ of $2 \mathrm{~N} \mathrm{HClO}_{4}, 2 \mathrm{ml}$ of $4 \%$ diphenylamine in glacial acetic acid, and $100 \mu \mathrm{l}$ of acetaldehyde $(1.6 \mathrm{mg} / \mathrm{ml})$, incubated at $37^{\circ} \mathrm{C}$ overnight, and the DNA quantitated by absorbance readings at $595 \mathrm{~nm}$ using calf thymus DNA as a standard.

Statistical analysis. All results are expressed as mean \pm 1 SEM. The significance of differences was analyzed by either the Student's $t$ test for unpaired data or one way ANOVA when three group comparisons were made. Duncan's test was used for intergroup comparisons (21).

\section{Results}

\section{Diet study 1 and uninephrectomy}

General parameters. The mean body weights of the rats between the $6 \%$ and $50 \%$ protein groups were not different at either the start of the study ( $244 \pm 5$ vs. $242 \pm 5 \mathrm{~g})$ or $3 \mathrm{~d}$ after dietary change ( $247 \pm 7$ vs. $247 \pm 5 \mathrm{~g}$ ). The mean body weight of the $50 \%$ group was higher $21 \mathrm{~d}$ after the change in the diets ( $273 \pm 6$ vs. $311 \pm 11 \mathrm{~g} ; P<0.05)$. The wet kidney weights were greater in the $50 \%$ protein group both at $3 \mathrm{~d}$ and $21 \mathrm{~d}$ when expressed as either the absolute weight or kidney wt/body wt (Table I). Urinary sodium excretion in a subset of animals ( $n$ $=4$ both groups) was not different between the $6 \%$ and $50 \%$ groups (283 \pm 21 vs. $290 \pm 62 \mu \mathrm{eq} / 24 \mathrm{~h} ; P=\mathrm{NS})$.

The mean body weights were not different between the sham operated and uninephrectomized group at the start of the study ( $254 \pm 4$ vs. $247 \pm 3 \mathrm{~g} ; P=\mathrm{NS}$ ) but were higher in the sham operated group at $7 \mathrm{~d}(285 \pm 4$ vs. $269 \pm 3 \mathrm{~g} ; P<0.05)$. In the animals whose kidneys were used for quantitation of renin mRNA the wet weight of the remaining left kidney was greater in the uninephrectomized group compared to the sham operated group (Table I). The kidney wt/body wt was greater in the uninephrectomized group compared to the sham group at 7 days and also compared to both the $3-\mathrm{d}$ and $21-\mathrm{d} 50 \%$ protein group (Table I).

The growth of the remaining kidney after uninephrectomy was predominantly hypertrophy as evidenced by increases in protein, RNA, and RNA/DNA with no significant changes in DNA content when compared to both the kidney removed at

Table I. Kidney Weights

\begin{tabular}{lrlc}
\hline & $n$ & Left kidney wt & Kidney wt/body wt \\
\hline & & \multicolumn{1}{c}{$g$} & $\times 10^{-3}$ \\
6\% Protein 3 days & 10 & $0.81 \pm 0.03$ & $3.27 \pm 0.06$ \\
50\% Protein 3 days & 10 & $1.08 \pm 0.03^{*}$ & $4.15 \pm 0.06^{*}$ \\
6\% Protein 21 days & 6 & $0.84 \pm 0.02$ & $3.08 \pm 0.06$ \\
50\% Protein 21 days & 6 & $1.27 \pm 0.05^{*}$ & $4.07 \pm 0.05^{*}$ \\
Sham 7 days & 5 & $1.07 \pm 0.03$ & $3.84 \pm 0: 06$ \\
UNX 7 days & 5 & $1.24+0.02^{*}$ & $4.65+0.06^{* \neq}$
\end{tabular}

Mean \pm SEM. Values are from diet study $1 .{ }^{*} P<0.00150 \%$ vs. $6 \%$ protein-fed animals and uninephrectomy (UNX) vs. sham operated animals. ${ }^{\ddagger} P<0.05 \mathrm{UNX}$ vs. $3 \mathrm{~d}$ and $21 \mathrm{~d} 50 \%$ protein-fed animals. 
Table II. Effect of Uninephrectomy on Kidney Growth and Composition

\begin{tabular}{lccc}
\hline & Sham 7 days & UNX time 0 & UNX 7 days \\
\hline Final body weight $(g)$ & $291 \pm 10$ & \multicolumn{2}{c}{$270 \pm 9^{*}$} \\
Kidney weight $(g)$ & $1.12 \pm 0.07$ & $0.99 \pm 0.04$ & $1.33 \pm 0.05^{* \pm}$ \\
Kidney/body weight & & & \\
$\quad\left(\times 10^{-3}\right)$ & $3.85 \pm 0.19$ & $3.86 \pm 0.08$ & $4.90 \pm 0.12^{* \neq}$ \\
Protein $($ mg/kidney) & $111.2 \pm 3.2$ & $102.7 \pm 1.28$ & $122.9 \pm 5.3^{* \neq}$ \\
RNA (mg/kidney) & $4.0 \pm 0.2$ & $3.5 \pm 0.1^{*}$ & $4.8 \pm 0.1^{* \neq}$ \\
DNA (mg/kidney) & $2.7 \pm 0.3$ & $2.7 \pm 0.2$ & $2.8 \pm 0.3$ \\
RNA/DNA & $1.46 \pm 0.10$ & $1.28 \pm 0.11^{*}$ & $1.72 \pm 0.20^{* \neq}$
\end{tabular}

Mean \pm SEM. $n=6$ for all groups. ${ }^{*} P<0.05$ vs. SHAM. ${ }^{\ddagger} P<0.05$ vs. UNX time 0 .

the time of uninephrectomy and to the left kidney of the sham operated group (Table II).

Northern and solution hybridization. Analysis of the Northern blots confirmed a single band for renal renin mRNA $(1,600 \mathrm{bp})$ and for renal and liver angiotensinogen mRNA $(1,800 \mathrm{bp})$ in all blots examined. Only data for renal renin mRNA at $3 \mathrm{~d}$ is shown (Fig. 1). The results on the Northern blots were not different from the results of the solution hybridization experiments. Fig. 1 shows an autoradiograph of the Northern blot of RNA extracted from the kidney $3 \mathrm{~d}$ after dietary change in six animals on the $6 \%$ protein diet and six animals on the $50 \%$ protein diet. Quantitation by densitometry demonstrated that the relative renin mRNA level for the $50 \%$ group was 2.7 -fold greater than the level of the $6 \%$ group ( $38 \pm 7$ vs. $14 \pm 3$ OD units; $P<0.05$ ). To more exactly quantify changes in renin and angiotensinogen mRNA, solution hybridization was performed. As demonstrated in Fig. 2 renin mRNA was higher in the $50 \%$ protein group compared to the $6 \%$ protein group at both $3 \mathrm{~d}(9.4 \pm 1.1$ vs. $5.3 \pm 0.4 \mathrm{pg} / \mu \mathrm{g}$ total RNA; $P<0.02)$ and $21 \mathrm{~d}(6.8 \pm 1.0$ vs. $3.5 \pm 0.4 \mathrm{pg} / \mu \mathrm{g}$ total RNA; $P<0.02)$ confirming the results of the Northern hybridization at $3 \mathrm{~d}$ and demonstrating the stimulatory effect of the high protein diet on renin mRNA.

There was no difference in angiotensinogen mRNA between the $50 \%$ and $6 \%$ protein groups in the kidney at either 3 d $(5.2 \pm 0.8$ vs. $6.8 \pm 0.6 \mathrm{pg} / \mu \mathrm{g}$ total RNA; $P=\mathrm{NS})$ or $21 \mathrm{~d}$ $(4.4 \pm 0.6$ vs. $5.0 \pm 1.0 \mathrm{pg} / \mu \mathrm{g}$ total RNA; $P=$ NS) (Fig. 3 ). The lack of change in angiotensinogen mRNA testifies to the specific effect that dietary protein has on stimulating only renin

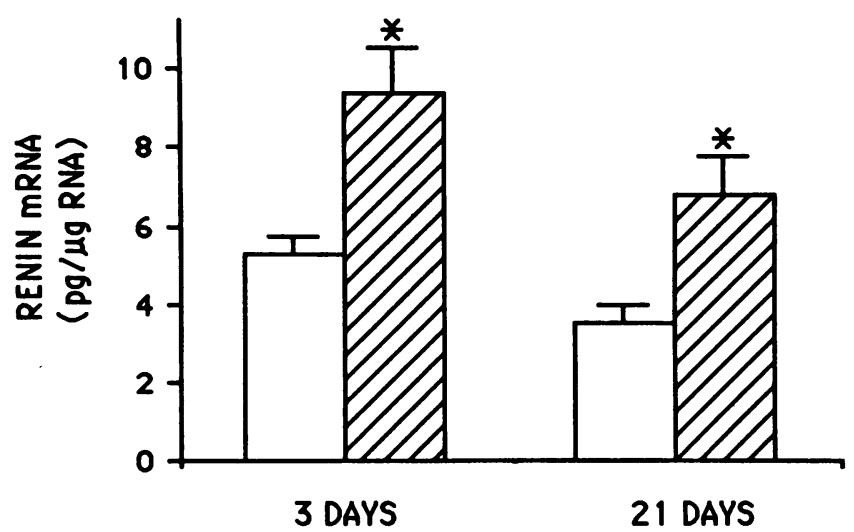

Figure 2. Effect of dietary protein on renal renin mRNA as determined by solution hybridization of total kidney RNA using a ${ }^{35} \mathrm{~S}$-labeled renin cRNA probe. The $6 \%$ protein-fed animals are represented by the open bars and the $50 \%$ protein-fed animals by the hatched bars. $n=10$ for both groups $3 \mathrm{~d}$ after dietary change and $n$ $=6$ for both groups $21 \mathrm{~d}$ after dietary change. Renin mRNA is expressed as picograms per microgram of total RNA and is the average of two determinations using 20 and $50 \mu \mathrm{g}$ of total kidney RNA. ${ }^{*} P<0.02$

mRNA. Although the amount of liver angiotensinogen mRNA was much greater than in the kidney, the amount was not different between the $50 \%$ and $6 \%$ protein group at either 3 d $(56.0 \pm 9.3$ vs. $60.1 \pm 8.3 \mathrm{pg} / \mu \mathrm{g}$ total RNA; $P=\mathrm{NS})$ or at $21 \mathrm{~d}$ (71.6 \pm 21.3 vs. $56.8 \pm 1.7 \mathrm{pg} / \mu \mathrm{g}$ total RNA; $P=$ NS) (Fig. 3). Renin mRNA was not detectable in the liver in Northern hybridizations with a renin cDNA probe.

The increase in kidney weight/body weight in the uninephrectomy compared to the sham group was similar to the increase seen in the $50 \%$ compared to the $6 \%$ protein group both averaging $28 \%$. In both cases the growth was predominantly hypertrophic (Table II and III). Despite this comparable degree of hypertrophy, and in contrast to the hypertrophy seen after dietary protein loading, renin mRNA was not significantly different in the uninephrectomized compared to the sham operated animals $(3.7 \pm 0.1$ vs. $3.4 \pm 0.1 \mathrm{pg} / \mu \mathrm{g}$ total RNA; $P=$ NS) (Fig. 4). This lack of change in renin mRNA indicates that the elevated renin mRNA with increased dietary protein is not simply attributable to renal growth.

\section{Diet study 2}

In this experiment low $(6 \%)$ and high (50\%) protein fed groups were compared to a group ingesting a more standard level of
$6 \%$ Protein

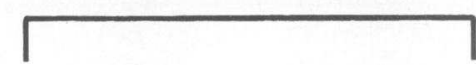

\section{$50 \%$ Protein}



Figure 1. Autoradiograph of northern blot of total kidney RNA (20 $\mu \mathrm{g})$ extracted from rats ingesting either a $6 \%$ or a $50 \%$ protein diet. A ${ }^{32} \mathrm{P}$-labeled nick-translated renin cDNA probe (pRen44.ceb) was used for hybridization. Autoradiograph was exposed for $36 \mathrm{~h}$. 


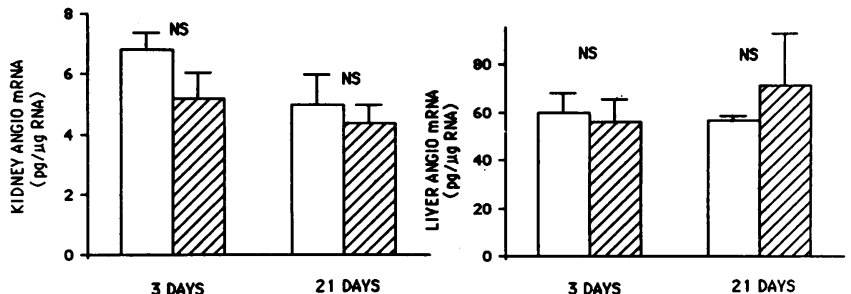

Figure 3. Effect of dietary protein on kidney (left graph) and liver (right graph) angiotensinogen mRNA as determined by solution hybridization of total kidney or liver RNA using a ${ }^{35}$ S-labeled angiotensinogen cRNA probe. The $6 \%$ protein-fed animals are represented by the open bars and the $50 \%$ protein-fed animals by the hatched bars. $n=10$ for both groups $3 \mathrm{~d}$ after dietary change and $n=6$ for both groups $21 \mathrm{~d}$ after dietary change. Angiotensinogen mRNA is expressed as picograms per microgram of total RNA and is the average of two determinations using 20 and $50 \mu \mathrm{g}$ of total kidney RNA and 0.5 and $2 \mu \mathrm{g}$ of total liver RNA.

dietary protein $(20 \%)$. Initial mean body weights were similar in the three groups (6\%: $243 \pm 1 \mathrm{~g} ; 20 \%: 244 \pm 3 \mathrm{~g}$; $50 \%$ : $244 \pm 3$ g). Final body weight was significantly higher in the $20 \%$ group (Table III). Kidney weights increased significantly as the level of dietary protein was raised. Protein, RNA, and RNA/DNA tended to increase with the level of dietary protein while DNA content remained stable between the three groups reflecting the predominant hypertrophic response of the kidney to increasing dietary protein (Table III).

Renin mRNA, as quantitated by solution hybridization, was significantly different in the three groups (50\%: 7.2 \pm 0.6 ; 20\%: $5.1 \pm 0.3 ; 6 \%: 3.3 \pm 0.4 \mathrm{pg} / \mu \mathrm{g}$ total RNA) (Fig. 5). The differences between the $6 \%$ and $50 \%$ groups confirm the findings of the first experiment. The intermediate level for renin mRNA in the $20 \%$ group demonstrate the inhibitory and stimulatory effects of the $6 \%$ and $50 \%$ protein diets, respectively. Since renin mRNA is expressed as a percentage of total kidney RNA, the rise in renin mRNA with increasing protein intake cannot simply be attributable to increases in total kidney RNA content. Changes in the absolute values between diet study 1 and diet study 2 were not significant, and likely reflect different groups of animals, the fact that the studies were not contemporaneous, as well as interassay variability.

Table III. Effect of Dietary Protein on Kidney Growth and Composition

\begin{tabular}{lccc}
\hline & $6 \%$ Protein & $20 \%$ Protein & $50 \%$ Protein \\
\hline Final body weight $(g)$ & $238 \pm 3$ & $253 \pm 4^{*}$ & $237 \pm 4^{\ddagger}$ \\
Kidney weight $(g)$ & $0.72 \pm 0.02$ & $0.84 \pm 0.02^{*}$ & $0.91 \pm 0.01^{* \ddagger}$ \\
Kidney/body weight & & & \\
$\quad\left(\times 10^{-3}\right)$ & $3.06 \pm 0.07$ & $3.39 \pm 0.05^{*}$ & $3.91 \pm 0.08^{* \ddagger}$ \\
Protein $($ mg/kidney) & $82.1 \pm 2.8$ & $101.2 \pm 5.0^{*}$ & $106.3 \pm 2.8^{*}$ \\
RNA (mg/kidney) & $2.5 \pm 0.2$ & $3.2 \pm 0.5$ & $4.6 \pm 0.2^{* \ddagger}$ \\
DNA (mg/kidney) & $2.5 \pm 0.2$ & $2.3 \pm 0.1$ & $2.6 \pm 0.1$ \\
RNA/DNA & $1.08 \pm 0.17$ & $1.28 \pm 0.23$ & $1.78 \pm 0.09^{*}$ \\
& & & \\
\end{tabular}

Mean \pm SEM. $n=6$ for all groups. Values are from diet study 2 , and are obtained $3 \mathrm{~d}$ after dietary assignment. ${ }^{*} P<0.05$ vs. $6 \%$. ${ }^{\ddagger} P<0.05$ vs. $20 \%$.

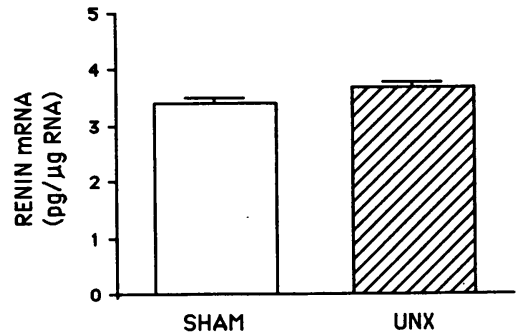

Figure 4. Effect of sham operation or right uninephrectomy (UNX) on renal renin mRNA as determined by solution hybridization using a ${ }^{35}$ S-labeled cRNA probe $7 \mathrm{~d}$ after surgery. $n=5$ for both groups. Renin mRNA is expressed as $\mathrm{pg} / \mu \mathrm{g}$ total RNA and is the average of determinations using 20 and $50 \mu \mathrm{g}$ of total kidney RNA. $P=$ NS.

\section{Discussion}

Dietary protein is a novel stimulus for increasing renal renin mRNA. The results of this study demonstrate that renal renin mRNA is increased in rats ingesting a $50 \%$ protein diet and decreased in animals ingesting a $6 \%$ protein diet compared to animals on a more normal $20 \%$ protein diet when examined 3 $\mathrm{d}$ after dietary change. The difference in renin mRNA between the $6 \%$ and $50 \%$ groups persisted at $21 \mathrm{~d}$. Dietary protein had no effect on the mRNA for the renin substrate, angiotensinogen, when kidney and liver RNA was examined. The lack of change in angiotensinogen mRNA indicates the specificity of the increase in renin mRNA. High dietary protein intake results in renal hypertrophy, as evidenced by the increases in RNA/DNA ratios, as well as an increase in renal blood flow and glomerular filtration rate (22). The hypertrophy and increased flows, however, cannot be responsible for the increase in renin mRNA since uninephrectomy, which resulted in a comparable degree of renal hypertrophy and which is also accompanied by increases in GFR and plasma flow had no effect on renin mRNA.

The mechanism by which high dietary protein stimulates renin remains speculative. A high protein diet results in increased prostaglandin production in normal animals and humans, in subtotally nephrectomized rats, and in patients with glomerular disease $(3-6,23)$. Prostaglandins are known to mediate renin release and may therefore be involved in the dietary protein induced changes in renin (24). High protein diets also result in increased loop of Henle sodium reabsorption and hence decreased sodium delivery to the macula densa, an effect that would also be expected to stimulate renin release (25).

Plasma renin activity in rats ingesting these identical $6 \%$ and $50 \%$ protein diets for $10 \mathrm{~d}$ was 2.8 -fold higher on the $50 \%$

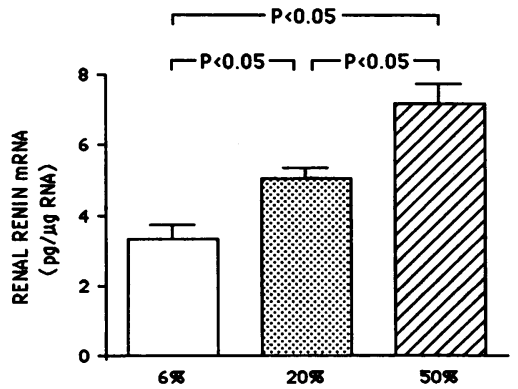

Figure 5. Effect of low (6\%), normal (20\%), and high $(50 \%)$ protein feeding on renin mRNA as determined by solution hybridization of total kidney RNA using a ${ }^{35}$ S-labeled renin cRNA probe. $n=6$ for each group. Renin mRNA is expressed as picograms per microgram total RNA and is the average of three determinations using 20 to $60 \mu \mathrm{g}$ of total kidney RNA. 
protein diet (4). A higher plasma renin activity also occurred in rats ingesting a $23 \%$ and $30 \%$ protein diet compared to a $6 \%$ protein diet $(4,26)$. Similarly, an increased plasma renin activity was noted by Fernandez-Repollet in rats ingesting a 23\% protein diet compared to those on a $6 \%$ protein diet (7). A high protein diet in both normal human subjects and those with a variety of glomerular diseases also results in increased plasma renin activity $(3,5)$. Changes in renin plasma clearance rate, secretion, and synthesis could each influence plasma renin activity. The current study supports augmented renin synthesis, as evidenced by the increase in renal renin mRNA, to explain at least in part the higher plasma renin activity induced by a high protein diet. Whether the increased renin mRNA was due to changes in renin gene transcription, posttranscriptional modification of the renin mRNA, or stabilization of the message remains to be determined.

Renal renin mRNA is increased by sodium depletion, converting enzyme inhibition, renal ischemia, and sympathetic stimulation $(10,11,27-29)$. The effect of dietary protein on renin mRNA has not been previously examined but based on the results of the current study we would add dietary protein to the list of conditions that alter renin mRNA. When co-expression of renin and angiotensinogen mRNA was examined in the kidney after sodium depletion, both were noted to be increased (10). The lack of change in angiotensinogen mRNA in the current study argues against changes in sodium balance as the cause for the change in renin mRNA. The identical electrolyte contents of the diet, and for the rats eating $6 \%$ and $50 \%$ protein the equivalent food intakes, and similar sodium excretion (measured in a subset of rats), all militate against changes in sodium balance as a factor in the effect of protein in altering renin $\mathrm{mRNA}$.

To ensure equivalent caloric and fat content, the carbohydrate content of the diets was adjusted. Differences in carbohydrate could potentially be responsible for the changes seen in renin mRNA, since a high carbohydrate diet (6\% protein) would be expected to stimulate insulin release. In the isolated perfused kidney insulin has been demonstrated to suppress renin secretion (30). However, another effect of high carbohydrate feeding is increased sympathetic nerve activity, an effect that would be expected to stimulate renin $(31,32)$. The isolated effects of dietary carbohydrate and protein on renin mRNA were not examined in this study.

Changes in dietary protein may affect the course of experimental and clinical renal disease (33). In fact, dietary protein restriction lessens renal injury in virtually all experimental models of renal disease, and in several long-term clinical studies (34). In many of the experimental models the beneficial effect of dietary protein restriction is related to the lowering of glomerular capillary pressure (33). Angiotensin II, the product of the renin-angiotensin cascade, has a preferential constricting effect on the efferent arteriole resulting in increases in glomerular capillary pressure $(9,33)$. Therefore, the beneficial effect of a low protein diet may be due, in part, to decreased plasma renin activity, which would most likely result in decreased renal angiotensin II, decreased efferent arteriolar resistance, and, hence, lowered glomerular capillary pressure. This possibility is supported by the finding of lowered efferent arteriolar resistance in rats with the remnant kidney model ingesting a $6 \%$ protein diet compared to a $20 \%$ protein diet (35). As well, in several experimental models pharmacologic angiotensin II blockade results in decreased proteinuria in rats fed a high but not a low protein diet $(26,36,37)$. Other nonhemodynamic effects of angiotensin II on renal growth, ammoniagenesis, and proton secretion may be additional consequences of the augmentation of renin gene expression by dietary protein, effects which may have both adaptive and pathologic consequences (38-40).

In conclusion, dietary protein is a novel stimulus for changes in renal renin mRNA. Rats ingesting a high protein diet have higher renal renin mRNA compared to rats ingesting a low protein diet. This change appears unrelated to renal hypertrophy and is not accompanied by changes in either kidney or liver angiotensinogen mRNA. The higher renin mRNA suggests that the higher plasma renin activity seen in rats and humans on a high protein diet is due to increased renin synthesis.

\section{Acknowledgments}

We thank R. Suek for expert secretarial assistance, K. R. Lynch for the renin and angiotensinogen cDNAs, and to Dr. C. Mariash for his helpful advice.

This work was supported by a U. S. Public Health Service Grant (AM-31437) and grants from the National Kidney Foundation of the Upper Midwest and the Minnesota Medical Foundation. Dr. Rosenberg was supported by a Research Fellowship from the Medical Research Council of Canada.

\section{References}

1. Muller, W. A., G. R. Faloona, and R. H. Unger. 1971. The influence of antecedent diet upon glucagon and insulin secretion. $N$. Engl. J. Med. 285:1450-1454.

2. Edozian, J. C., N. Niehaus, M. H. Mar, T. Makoui, and B. R. Switzer. 1978. Diet-hormone interrelationships in the rat. J. Nutr. 108:1767-1776.

3. Rosenberg, M. E., J. E. Swanson, B. L. Thomas, and T. H. Hostetter. 1987. Glomerular and hormonal responses to dietary protein intake in human renal disease. Am. J. Physiol. 253:F1083-F1090.

4. Paller, M. S., and T. H. Hostetter. 1986. Dietary protein increases plasma renin and reduces pressor reactivity to angiotensin II. Am. J. Physiol. 251:F34-F39.

5. Daniels, B. S., and T. H. Hostetter. 1988. Effect of dietary protein on vasoactive hormones. Kidney Int. 33:260. (Abstr.)

6. Levine, M. M., M. A. Kirschenbaum, A. Chaudhari, M. W. Wong, and N. S. Bricker. 1986. Effect of protein on glomerular filtration rate and prostanoid synthesis in normal and uremic rats. Am. J. Physiol. 251:F635-F641.

7. Fernández-Repollet, E., E. Tapia, and M. Martínez-Maldonado. 1987. Effects of angiotensin-converting enzyme inhibition on altered renal hemodynamics induced by low protein diet in the rat. J. Clin. Invest. 80:1045-1049.

8. Mansy, H., D. Patel, J. S. Tapson, J. Fernandez, S. Tapster, A. D. Torrance, and R. Wilkinson. 1987. Four methods to recruit renal functional reserve. Nephrol. Dial. Transplant. 2:228-232.

9. Edwards, R. M. 1983. Segmental effects of norepinephrine and angiotensin II on isolated renal microvessels. Am. J. Physiol. 244:F526-F534.

10. Ingelfinger, J. R., R. E. Pratt, K. Ellison, and V. J. Dzau. 1986. Sodium regulation of angiotensinogen mRNA expression in rat kidney cortex and medulla. J. Clin. Invest. 78:1311-1315.

11. Gomez, R. A., K. R. Lynch, R. L. Chevalier, A. D. Everett, D. W. Johns, N. Wilfong, M. J. Peach, and R. M. Carey. 1988. Renin and angiotensinogen gene expression and intrarenal renin distribution during ACE inhibition. Am. J. Physiol. 254:F900-F906.

12. Jump, D. B., P. Narayan, H. Towle, and J. H. Oppenheimer. 
1984. Rapid effects of triiodothyronine on hepatic gene expression. $J$. Biol. Chem. 259:2789-2797.

13. Maniatis, T., E. F. Fritsch, and J. Sambrook. 1982. Molecular cloning: A Laboratory Manual. Cold Spring Harbor Laboratory, Cold Spring Harbor, NY.

14. Mariash, C. N., S. Seelig, and J. H. Oppenheimer. 1982. A rapid, inexpensive, quantitative technique for the analysis of two-dimensional electrophoretograms. Anal. Biochem. 121:388-394.

15. Durnam, D. M., and R. D. Palmiter. 1983. A practical approach for quantitating specific mRNAs by solution hybridization. Anal. Biochem. 131:385-393.

16. Burnham, C. E., C. L. Hawelu-Johnson, B. M. Frank, and K. R. Lynch. 1987. Molecular cloning of rat renin cDNA and its gene. Proc. Natl. Acad. Sci. USA. 84:5605-5609.

17. Lynch, K. R., V. I. Simnad, E. T. Ben-Ari, and J. C. Garrison. 1986. Localization of preangiotensinogen messenger RNA sequences in the rat brain. Hypertension. 8:540-543.

18. Melton, D. A., P. A. Krieg, M. R. Rebagliati, T. Maniatis, K. Zinn, and M. R. Green. 1984. Efficient in vitro synthesis of biologically active RNA and RNA hybridization probes from plasmids containing a bacteriophage SP6 promoter. Nucleic Acid Res. 12:70357056.

19. Fleck, A., and H. N. Munro. 1962. The precision of ultraviolet absorption measurements in the Schmidt-Thannhauser procedure for nucleic acid estimation. Biochem. Biophys. Acta. 55:571-583.

20. Giles, K., and A. Meyers. 1965. An improved diphenylamine method for the estimation of deoxyribonucleic acid. Nature (Lond.) 206:93.

21. Snedecor, G. W., and W. G. Cochran. 1980. Statistical Methods. Iowa State University Press, Ames, IA. 215-237.

22. Halliburton, I. W. 1969. The effect of unilateral nephrectomy and of diet on the composition of the kidney. In Compensatory Renal Hypertrophy. W. W. Nowinski and R. J. Goss, editors. Academic Press, Inc., New York. 102-130.

23. Don, B. R., S. Blake, F. N. Hutchison, G. A. Kaysen, and M Schambelan. 1989. Dietary protein intake modulates glomerular eicosanoid production in the rat. Am. J. Physiol. 256:F711-F718.

24. Gerber, J. G., R. A. Branch, A. S. Nies, J. F. Gerkens, D. G. Shand, J. Hollifield, and J. A. Oates. 1978. Prostaglandins and renin release: assessment of renin secretion following infusion of $\mathrm{PGI}_{2}, \mathrm{E}_{2}$, and $\mathrm{D}_{2}$ into the renal artery of anesthetized dogs. Prostaglandins. 15:81-88.

25. Seney, F. D., Jr., A. E. G. Persson, and F. S. Wright. 1987. Modification of tubuloglomerular feedback signal by dietary protein. Am. J. Physiol. 252:F83-F90.

26. Rosenberg, M. E., and T. H. Hostetter. 1988. Acute angiotensin
II blockade reduces proteinuria in rats on a high but not a low protein diet. Kidney Int. 33:383. (Abstr.)

27. Dzau, V. J., D. W. Burt, and R. E. Pratt. 1988. Molecular biology of the renin-angiotensin system. Am. J. Physiol. 255:F563F573.

28. Moffett, R. B., R. A. McGowan, and K. W. Gross. 1986. Modulation of kidney renin messenger RNA levels during experimentally induced hypertension. Hypertension. 8:874-882.

29. Dzau, V. J., J. E. Carlton, and T. Brody. 1987. Sequential changes in renin secretion-synthesis coupling in response to acute beta adrenergic stimulation. Clin. Res. 35:604a. (Abstr.)

30. Cohen, A. J., P. Laurens, and J. C. S. Fray. 1983. Suppression of renin secretion by insulin: dependence on extracellular calcium Am. J. Physiol. 245:E531-E534.

31. Landsberg, L., and J. B. Young. 1978. Fasting, feeding, and regulation of the sympathetic nervous system. N. Engl. J. Med. 298:1295-1301.

32. Davis, J. O., and R. H. Freeman. 1976. Mechanisms regarding renin release. Physiol. Rev. 56:1-56.

33. Brenner, B. M., T. W. Meyer, and T. H. Hostetter. 1982. Dietary protein intake and the progressive nature of kidney disease: the role of hemodynamically mediated glomerular injury in the pathogenesis of progressive glomerular sclerosis in aging, renal ablation, and intrinsic renal disease. N. Engl. J. Med. 307:652-659.

34. Mitch, W. E. 1984. The influence of diet on the progression of renal insufficiency. Annu. Rev. Med. 35:249-264.

35. Nath K. A., S. M. Kren, and T. H. Hostetter. 1986. Dietary protein restriction in established renal injury in the rat. J. Clin. Invest. 78:1199-1205.

36. Hutchison, F. N., M. Schambelan, and G. A. Kaysen. 1987. Modulation of albuminuria by dietary protein and converting enzyme inhibition. Am. J. Physiol. 253:F719-F725.

37. Cartwright, M. E., and R. S. Jaenke. 1988. Effects of dietary protein and captopril on glomerular permselectivity in rats with unilateral nephrectomy. Lab. Invest. 59:492-499.

38. Norman, J., B. Badie-Dezfooly, E. P. Nord, I. Kurtz, J. Schlosser, A. Chaudhari, and L. G. Fine. 1987. EGF-induced mitogenesis in proximal tubular cells: potentiation by angiotensin II. Am. J. Physiol. 253:F299-F309.

39. Nagami, G. T. 1989. Effect of angiotensin II on ammonia production by isolated perfused mouse proximal tubules. Kidney Int. 35:460. (Abstr.).

40. Liu, F.-Y., and M. G. Cogan. 1987. Angiotensin II: a potent regulator of acidification in the rat early proximal convoluted tubule. J. Clin. Invest. 80:272-275. 